\title{
Baltic Sea harbour porpoise populations: status and conservation needs derived from recent survey results
}

\author{
Harald Benke ${ }^{1}$, Stefan Bräger ${ }^{1,2}$, Michael Dähne ${ }^{1,4}$, Anja Gallus ${ }^{1}$, \\ Sophie Hansen ${ }^{1}$, Christopher G. Honnef ${ }^{1}{ }^{\text {, Martin Jabbusch }}{ }^{1}$, Jens C. Koblitz ${ }^{1, *}$, \\ Kathrin Krügel ${ }^{1}$, Alexander Liebschner ${ }^{3}$, Ingo Narberhaus ${ }^{3}$, Ursula K. Verfuß ${ }^{1,5}$ \\ ${ }^{1}$ German Oceanographic Museum (DMM), 18439 Stralsund, Germany \\ ${ }^{2}$ The Whale Museum, Friday Harbor, Washington 98250, USA \\ ${ }^{3}$ Federal Agency for Nature Conservation (BfN), 18581 Putbus/Rügen, Germany \\ ${ }^{4}$ Present address: Institute for Terrestrial and Aquatic Wildlife Research (ITAW), \\ University of Veterinary Medicine Hannover, Foundation, 25761 Büsum, Germany \\ ${ }^{5}$ Present address: SMRU Marine Ltd., St. Andrews KY16 9SR, UK
}

\begin{abstract}
During recent decades, the 2 distinct harbour porpoise populations of the Baltic Sea have decreased sharply in abundance. The Baltic Proper population is down to a few hundred individuals and is regarded as 'Critically Endangered' by IUCN; the more abundant Belt Sea population also appears to have experienced a severe decline. We summarize the results of extensive static acoustic monitoring in the German part of the Baltic Sea and compare them to published results of aerial and acoustic surveys. Acoustic monitoring confirmed seasonal changes in detection rates consistent with proposed east-west migrations. Detection rates, and thus presumably porpoise density, decrease from west to east from a long-term mean (2002 to 2012) of $94 \%$ detection-positive days per month (DPD mo ${ }^{-1}$ ) around the island of Fehmarn and $71 \%$ DPD mo ${ }^{-1}$ in Kadet Trench to $4.4 \%$ DPD mo ${ }^{-1}$ in Pomeranian Bay as one crosses the putative population boundary. Acoustic monitoring results show a recent increase in porpoise registration rates in the Kadet Trench and in Pomeranian Bay, although this does not necessarily indicate a population increase. This large dataset supports the previously suggested proposition that each population uses the boundary waters in Pomeranian Bay alternately, leading to the presence of registration peaks in (late) summer by Belt Sea porpoises, and in winter by Baltic Proper animals. The critical status of porpoises in the Baltic Sea highlights the urgent need for protective measures which still await national and international implementation.
\end{abstract}

KEY WORDS: Acoustic monitoring $\cdot$ Baltic Sea $\cdot$ Distribution patterns $\cdot$ Generalized Additive Mixed Model $\cdot$ Phocoena phocoena $\cdot$ Population status $\cdot$ Seasonal movements

\section{INTRODUCTION}

The harbour porpoise Phocoena phocoena is the only cetacean species that regularly reproduces in the Baltic Sea, with a peak appearance of calves occurring in late summer, according to long-term stranding datasets (Börjesson \& Read 2003, Siebert et

*Corresponding author: jens.koblitz@meeresmuseum.de al. 2006). Genetic and morphometric studies concluded that 3 separate harbour porpoise populations occur in the Baltic Sea and adjacent waters, starting with the North Sea population extending into the Skagerrak. Within the Baltic Sea (see Fig. 1), 2 populations or management units can be distinguished in the waters between Skagen (northernmost point of

() The authors 2014. Open Access under Creative Commons by Attribution Licence. Use, distribution and reproduction are unrestricted. Authors and original publication must be credited. 
Denmark) in the west and the Gulf of Finland in the east (Tiedemann et al. 1996, Berggren et al. 1999, Huggenberger et al. 2002, Wiemann et al. 2010, Teilmann et al. 2011, Galatius et al. 2012). Using satellite tracking results, Teilmann et al. (2011) determined the boundaries between the Skagerrak (i.e. the North Sea) population and the Belt Sea population. Gallus et al. (2012) proposed a geographically overlapping, albeit seasonally separated distribution of the Belt Sea and the Baltic Proper population in German waters northeast of the island of Rügen.

Harbour porpoise density and distribution in the central Baltic Sea or Baltic Proper (mostly between the German island of Rügen and the Finnish Archipelago) has declined considerably during the last century (Koschinski 2001) and has led directly to a 'Critically Endangered' status of the harbour porpoise population in the Baltic Proper (Hammond et al. 2008). International attempts to introduce protection measures for harbour porpoises in these waters during the past $20 \mathrm{yr}$, e.g. to introduce marine protected areas or to reduce fisheries impact (European Council 1992, HELCOM 1996, ASCOBANS 2002), have had no measurable success so far.

Historically, the range of the harbour porpoise in the Baltic Sea extended northward to the Gulf of Bothnia and eastwards into the Gulf of Riga and the entrance of the Gulf of Finland (Kinze 1995, Tomilin 1957 in Koschinski 2001). Currently, records of sightings and strandings are largely restricted to the Kattegat and Belt Sea as well as along the German, Polish and eastern Swedish Baltic Sea coasts, with the latter 2 regions reporting the lowest numbers. Nonetheless, even today harbour porpoises still occur throughout the Baltic Proper, as indicated by opportunistic sightings, occasional bycatch and strandings (http://maps.helcom.fi/website/mapservice/index. html).

Until the 1940s, the decline was likely caused by hunting as well as periodic mass mortalities associated with severe winter ice conditions (Kinze 1995, Koschinski 2001). For the second half of the last century, threats such as bycatch, toxins and noise pollution, prey depletion due to overfishing, and habitat deterioration (e.g. destruction of estuarine habitats during port construction or devaluation of benthic feeding grounds due to hypoxia caused by eutrophication) were identified as probable causes for the severe decline in the Baltic Proper harbour porpoise population (cf. ASCOBANS 2002, 2009). Early studies suggested that the impacts of fishing (Andersen 1974, 1982, Clausen \& Andersen 1988, Benke 1994, Berggren 1994) and pollution (Andersen \& Rebsdorff
1976, Granby \& Kinze 1991, Kannan et al. 1993, Falandysz et al. 1994, Szefer et al. 1994) had a particularly devastating effect.

The Baltic Proper population (east of Darss Sill, thus also inhabiting the Pomeranian Bay) is now too small to be estimated accurately by traditional linetransect survey methods. It may number as low as a few hundred individuals spread out over a very large area (Berggren et al. 2002, 2004, Hammond et al. 2008). The Belt Sea population still numbers 1 or 2 orders of magnitude higher over a much smaller area (Hammond et al. 2002, Sveegaard et al. 2013).

Ten EU member states are currently parties to the Agreement on the Conservation of Small Cetaceans of the Baltic, North East Atlantic, Irish and North Seas (ASCOBANS), a regional inter-governmental agreement for the restoration of biological management stocks of small cetaceans under UNEP/CMS. To achieve that, the ASCOBANS Recovery Plan for Baltic Harbour Porpoises (also known as the Jastarnia Plan; ASCOBANS 2002, 2009) recommends immediately reducing the bycatch rate, improving knowledge in key subject areas as quickly as possible, and seeks to 'develop more refined (quantitative) recovery targets as new information becomes available on population status, bycatch and other threats' (ASCOBANS 2009, p. 14). It also recommends the immediate identification of high-risk areas with 'extremely high priority' based on porpoise distribution. Furthermore, the plan states the necessity to develop and apply new techniques (e.g. acoustic monitoring) for assessing trends in abundance. In 2012, ASCOBANS also adopted a Conservation Plan for the Harbour Porpoise Population in the Western Baltic, the Belt Sea and the Kattegat to protect the Belt Sea population (ASCOBANS 2012).

In addition to these agreements, the Habitats Directive directly obliges EU member states to designate Special Areas of Conservation (SAC) for harbour porpoises as well as to provide strict protection for all cetacean species within their entire marine waters. Within the German part of the Baltic Sea, 24 'Natura 2000' sites have been adopted as Sites of Community Importance for harbour porpoises (http://natura2000.eea.europa.eu/), requiring monitoring of the conservation status for all listed species. The resulting assessments form the basis to develop necessary conservation measures and management plans, and to ensure that the population of the target species (in this case the harbour porpoise) is maintained at a 'favourable conservation status' in its natural range (European Council 1992). In the latest regular assessment of the conservation status of the harbour porpoise under the Habitats Directive, Den- 
mark, Germany, Latvia, Poland and Sweden reported a conservation status of 'unfavourable/bad' for the Baltic Sea harbour porpoise populations, with future prospects categorised as 'poor' or 'deteriorating' (http:// bd.eionet.europa.eu/activities/Reporting/Article_17/ Reports_2007/index_html). To allow a comparison of our data we summarize all published visual and acoustic surveys for harbour porpoises in the Baltic Sea.

\section{Survey methods to monitor harbour porpoises in the Baltic Sea}

Species conservation and management of human activities requires knowledge of the status of the species - including current densities and ranging patterns - to be able to detect changes in abundance and distribution. Information on spatial and temporal variation in abundances is needed to determine the effectiveness of management and mitigation measures (cf. Evans \& Hammond 2004). Abundance and distribution of harbour porpoise can be determined using a variety of methods, including visual and acoustic techniques (Table 1).

Previously employed visual surveys for harbour porpoises

Traditionally, the study of wild cetaceans has been dependent on visual observation. Cetaceans can be sighted as they surface in order to breathe, allowing data collection on their surface behaviour, abundance and distribution. Visual observations can be made from land, boat or plane, usually over a limited time frame. Visual methods, however, have limitations: observations are generally restricted to daylight hours and periods of fine weather (for shipborne surveys usually at sea states of $\leq 2$ Beaufort sea state [Bft] and under 'good' conditions for aerial surveys; Teilmann 2003, Berggren et al. 2004, respectively). Under appropriate sighting conditions, low flying high-winged aircraft with bubble windows represent a good platform for surveys. In low-density areas such as the Baltic Proper, however, the usefulness of visual survey techniques appears to be limited, and produces wide confidence limits due to low sighting rates (e.g. Berggren et al. 2004). Opportunistic sightings require some caution when interpreting the data, as data quality may be biased by the temporal and spatial distribution of vessels and observers (Siebert et al. 2006). It may, however, be possible to correct opportunistic sighting data for effort to some degree, and to calculate relative occurrence for eparate areas (Cooke 1984, Loos et al. 2010).

Shipboard surveys. Two dedicated international surveys were carried out to estimate the abundance of harbour porpoises and other cetacean species in European waters: the 'Small cetacean abundance survey in the North Sea and adjacent waters' (SCANS-I) in July of 1994 (Hammond et al. 2002), and 'Small cetaceans in the European Atlantic and North Sea' (SCANS-II) in July of 2005 (Hammond et al. 2013). The results of these 2 surveys were recently re-analyzed for the Belt Sea area: the abundance of

Table 1. Phocoena phocoena. Surveying methodology and monitoring projects in the Baltic Sea

\begin{tabular}{|c|c|c|c|c|}
\hline $\begin{array}{l}\text { Survey } \\
\text { methodology }\end{array}$ & $\begin{array}{l}\text { Method } \\
\text { employed }\end{array}$ & $\begin{array}{l}\text { Unit or quantity } \\
\text { measured }\end{array}$ & $\begin{array}{l}\text { Platform } \\
\text { or method }\end{array}$ & $\begin{array}{l}\text { Examples from } \\
\text { the Baltic Sea }\end{array}$ \\
\hline \multirow[t]{3}{*}{ Visual } & $\begin{array}{l}\text { Transect } \\
\text { surveys }\end{array}$ & $\begin{array}{l}\text { Distribution, density } \\
\text { and abundance }\end{array}$ & Aerial & $\begin{array}{l}\text { Heide-Jørgensen et al. (1992, 1993), } \\
\text { Berggren et al. (2004), Scheidat et al. (2008) }\end{array}$ \\
\hline & $\begin{array}{l}\text { Transect } \\
\text { surveys }\end{array}$ & $\begin{array}{l}\text { Distribution, density } \\
\text { and abundance }\end{array}$ & Shipboard & $\begin{array}{l}\text { Hammond et al. (2002, 2013), Gillespie et al. (2005), } \\
\text { Sveegaard et al. (2013) }\end{array}$ \\
\hline & $\begin{array}{l}\text { Opportunistic } \\
\text { sightings }\end{array}$ & $\begin{array}{l}\text { Distribution and } \\
\text { relative density }\end{array}$ & Sailor reports & Loos et al. (2010) \\
\hline \multirow[t]{2}{*}{ Acoustic } & Transect survey & $\begin{array}{l}\text { Distribution, density } \\
\text { and vocal abundance }\end{array}$ & Shipboard & Gillespie et al. (2005), Sveegaard et al. (2011b) \\
\hline & $\begin{array}{l}\text { Static acoustic } \\
\text { monitoring }\end{array}$ & $\begin{array}{l}\text { Distribution, density } \\
\text { and vocal abundance }\end{array}$ & $\begin{array}{c}\text { Moored click } \\
\text { detectors } \\
\text { (T-PODs) }\end{array}$ & Verfuß et al. (2007, 2008), Gallus et al. (2012) \\
\hline Strandings & $\begin{array}{l}\text { Beachcast \& } \\
\text { delivered bycatch }\end{array}$ & Occurrence & $\begin{array}{l}\text { Carcass retrieval } \\
\text { \& necropsy }\end{array}$ & Siebert et al. (2006) \\
\hline $\begin{array}{l}\text { Individual } \\
\text { markings }\end{array}$ & $\begin{array}{l}\text { Long-term } \\
\text { localisations }\end{array}$ & $\begin{array}{l}\text { Movements and } \\
\text { habitat use }\end{array}$ & $\begin{array}{l}\text { Satellite- } \\
\text { transmitters }\end{array}$ & Sveegaard et al. (2011a), Teilmann et al. (2013) \\
\hline
\end{tabular}


this population was estimated to be 27923 (95\% CI = 11916 to 65432 ) individuals in 1994, 10614 (95\% CI $=6218$ to 18117 ) individuals in 2005, and 18495 (95\% CI = 10892 to 31406 ) individuals in 2012 (Sveegaard et al. 2013). Although not significantly different at an $\alpha$-level of $5 \%$, these estimates likely indicate a serious decline of the Belt Sea population. Shipboard surveys in Polish, Swedish and German waters of the Baltic Proper did not result in abundance estimates for the Baltic Proper and the southern Belt Sea due to a lack of porpoise sightings (Gillespie et al. 2005).

Aerial surveys. The first aerial surveys for harbour porpoises in the Belt Sea were undertaken in 1991 and 1992 (Heide-Jørgensen et al. 1992, 1993). These were followed by additional aerial surveys in 1995 and 1996 covering Kiel and Mecklenburg Bight as well as the waters around the island of Rügen (German Federal Ministry for Education and Research data in Koschinski 2001, Siebert et al. 2006). In the southwestern part of the Baltic Proper, 2 aerial surveys were conducted for harbour porpoise: one in June 1995, generating an abundance estimate of 599 (95\% CI $=200$ to 3300) porpoise groups based on 3 sighted animals (Berggren et al. 2004) and another one in 2002 resulting in an abundance estimate of 93 (95\% CI $=10$ to 460 ) porpoise groups based on 2 sightings of single individuals (Berggren et al. 2004). This decline was not statistically significant due to the small sample sizes. The German part of the Baltic Sea and adjacent Danish Belt Sea waters were surveyed in great detail by Scheidat et al. (2008) with 2 to 5 annual aerial surveys between 2002 and 2006 . Resulting abundance estimates ranged from 1352 (95\% CI $=230$ to 3840 ) to 2905 (95\% CI = 1308 to 6384 ) individuals, with highest densities occurring in Kiel and Mecklenburg Bights, and the lowest in Pomeranian Bay.

A comparison of survey results are given in Tables 2 \& 3, with extrapolated densities in smaller subareas. In the Kattegat, Inner Danish Waters, Kiel Bight, Mecklenburg Bight and Kadet Trench, the porpoise densities range from 0.7 to 0.1 ind. $\mathrm{km}^{-2}$, declining from west to east. Densities of 0.001 to 0.1 ind. $\mathrm{km}^{-2}$ were extrapolated for the waters around Rügen and in the Pomeranian Bay. The only 2 surveys in the Baltic Proper recorded densities of 0.013 ind $\mathrm{km}^{-2}$ and 0.001 ind. $\mathrm{km}^{-2}$, respectively, thus highlighting the continuing low abundance of harbour porpoises in the Baltic Sea.

Opportunistic sightings. Although porpoise density in the Baltic Proper is now extremely low, harbour porpoises still occur throughout the Baltic Sea as shown by bycatch and occasional opportunistic sightings at the northeastern end of the porpoise range in Finland (http://maps.helcom.fi/website/map service/index.html). Opportunistic sightings and occasional strandings of this species have been reported in almost all countries surrounding the Baltic Sea. From 2002 to 2010, opportunistic sightings of harbour porpoises in the Baltic Sea were collected by the Society for the Conservation of Marine Mammals (GSM). Since 2011, this project has been continued by the German Oceanographic Museum (www. meeresmuseum.de/wissenschaft/schweinswale/ sichtungen.html). The sightings are reported by sailors and other members of the general public and are subsequently included into the HELCOM porpoise database, thus making them widely available.

\section{Previously employed acoustic surveys for harbour porpoises}

Compared to visual surveys, which are limited to ideal sighting conditions, acoustic monitoring with hydrophones (either towed behind a vessel or deployed statically) also allows for data collection at night and under adverse weather conditions (cf. Mellinger et al. 2007). For static acoustic monitoring with self-contained click detectors, acoustic data loggers are moored at sea. Timing Porpoise Detectors (T-PODs; Chelonia) register the echolocation signals of porpoises, thus enabling data aquisition under challenging conditions and surveying animals in their environment without causing disturbance. The effective detection radius of the instruments was measured by Kyhn et al. (2012) to be 17 to 108 $\mathrm{m}$ within 15 to $60 \mathrm{~s}$ snapshots, determined by tracking porpoises around T-PODs and comparing visual detection distances with simultaneous acoustic detections. The porpoise detectors are highly suitable for long-term monitoring (Verfuß et al. 2007) at low cost per detection. Severe environmental conditions (such as ice formation during winter months) and bottom-trawling may pose a challenge for the deployment of instruments or produce large amounts of background noise. Moreover, drifting sea-ice and ship traffic in general are a threat to moored devices.

Towed hydrophone arrays. During 2001 and 2002, acoustic surveys with a towed hydrophone array were carried out in the southern Baltic Sea (Gillespie et al. 2005). The aim was to analyze harbour porpoise distribution and relative abundance in Kiel and Mecklenburg Bights, the Little Belt and the area east 


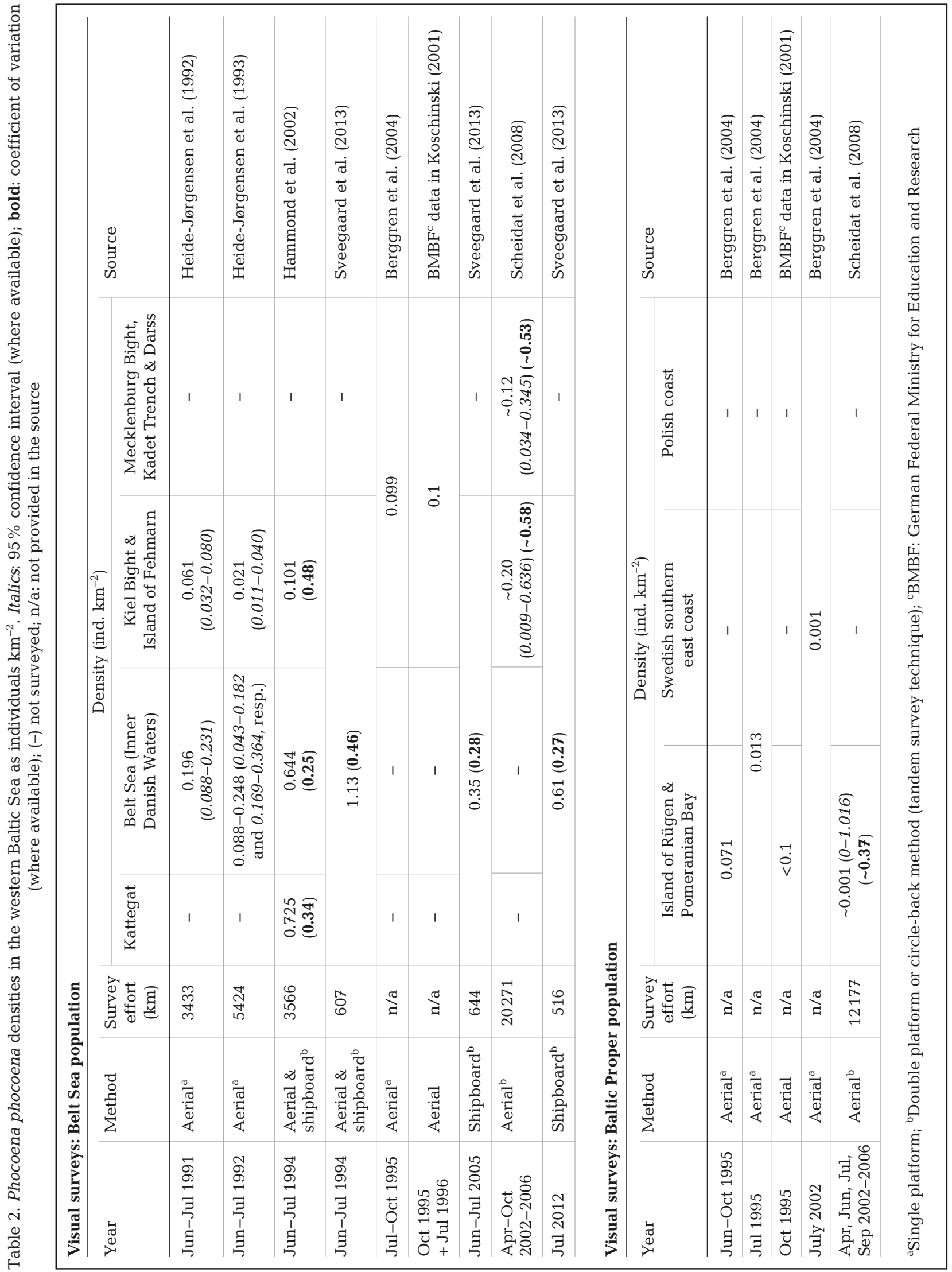


Table 3. Phocoena phocoena. Number of monitoring days and registration rates as a proportion (\%) of detection-positive days per month (DPD mo ${ }^{-1}$ ) during stationary acoustic surveys in the western Baltic Sea. Study period: Jan-Dec in all years

\begin{tabular}{|c|c|c|c|c|c|c|c|}
\hline \multirow[t]{2}{*}{ Study period } & \multirow{2}{*}{$\begin{array}{c}\text { No. of } \\
\text { days }\end{array}$} & \multicolumn{2}{|c|}{ _ Belt Sea population } & \multirow[b]{2}{*}{$\begin{array}{c}\text { Mecklenburg } \\
\text { Bight, Kadet } \\
\text { Trench \& Darss }\end{array}$} & \multicolumn{2}{|c|}{ — Baltic Proper population - } & \multirow[t]{2}{*}{ Source } \\
\hline & & $\begin{array}{l}\text { Kiel Bight } \\
\text { \& Island } \\
\text { of Fehmarn }\end{array}$ & $\begin{array}{l}\text { No. of } \\
\text { days }\end{array}$ & & $\begin{array}{c}\text { No. of } \\
\text { days }\end{array}$ & $\begin{array}{l}\text { Island of Rügen } \\
\text { \& Pomeranian } \\
\text { Bay }\end{array}$ & \\
\hline $2002-2005$ & 3510 & $30-100 \%$ & 6083 & $0-100 \%$ & 6725 & $0-15 \%$ & Verfuß et al. (2007) \\
\hline $2005-2006$ & 4209 & $15-100 \%$ & 5413 & $0-100 \%$ & 9170 & $0-15 \%$ & Verfuß et al. (2008) \\
\hline $2005-2007$ & - & - & - & - & 11890 & $1.9 \%$ & Gallus et al. (2012) \\
\hline $2002-2012$ & 5024 & $\begin{array}{c}94.4 \% \\
(32-100 \%)\end{array}$ & 8297 & $\begin{array}{c}70.6 \% \\
(0-100 \%)\end{array}$ & 9604 & $\begin{array}{c}4.4 \% \\
(0-84 \%)\end{array}$ & This study \\
\hline
\end{tabular}

of the Darss Sill including waters up to the coasts of Sweden in the North and Poland in the South. The outcome revealed a very low detection rate for porpoises in the Baltic Proper compared to the other areas (Kiel and Mecklenburg Bights and the Little Belt), confirming the critically endangered status of the Baltic Proper population (Gillespie et al. 2005). Based on 6 acoustic surveys with a towed hydrophone in the Kattegat and northern Belt Sea in 2007, Sveegaard et al. (2011b) were able to confirm the temporal and spatial distribution of harbour porpoises previously obtained from $10 \mathrm{yr}$ of harbour porpoise satellite tracking data.

Static acoustic monitoring. Static acoustic monitoring is an effective method to survey cetaceans, especially in areas with rare registrations due to low population densities such as the harbour porpoise in the Baltic Proper (Gallus et al. 2012), the vaquita Phocoena sinus in the Gulf of California, Mexico (Gerrodette et al. 2011), Hector's dolphin Cephalorhynchus hectori in New Zealand (Rayment et al. 2009, 2011), Heaviside's dolphin Cephalorhynchus heavisidii in Namibia (Leeney et al. 2011), and the Ganges River dolphin Platanista gangetica in India (SasakiYamamoto et al. 2013). In the future, statistical methods may allow the extrapolation of acoustic detections to animal abundances, which requires a detection function including addi- 5 tional information about abiotic factors, and biotic factors such as the echolocation behaviour of porpoises (Kyhn et al. 2008, 2012).

The compilation presented here summarizes published and unpublished information from stationary acoustic monitoring, with informa- 5 tion from acoustic and visual shipboard surveys as well as aerial sur- veys and opportunistic sightings. These results of recent research on harbour porpoises in the Baltic Sea are synthesized to assess the status of the 2 harbour porpoise populations: the potentially endangered Belt Sea population and the critically endangered Baltic Proper population.

\section{MATERIALS AND METHODS}

\section{Study area}

The study area extends throughout the German part of the Baltic Sea from the Danish border in the west near the island of Fehmarn, to the Polish border in the east near the mouth of the river Odra (Fig. 1). The Baltic Sea is the largest brackish sea in the world, covering an area of $404364 \mathrm{~km}^{2}$ (from approximately $54^{\circ}$ to $66^{\circ} \mathrm{N}$ and $10^{\circ}$ to $30^{\circ} \mathrm{E}$ ) with special geographical, climatological and oceanographic characteristics. Due to its shallow depth with an average of only $53 \mathrm{~m}$ (maximum depth is $451 \mathrm{~m}$ ), its volume

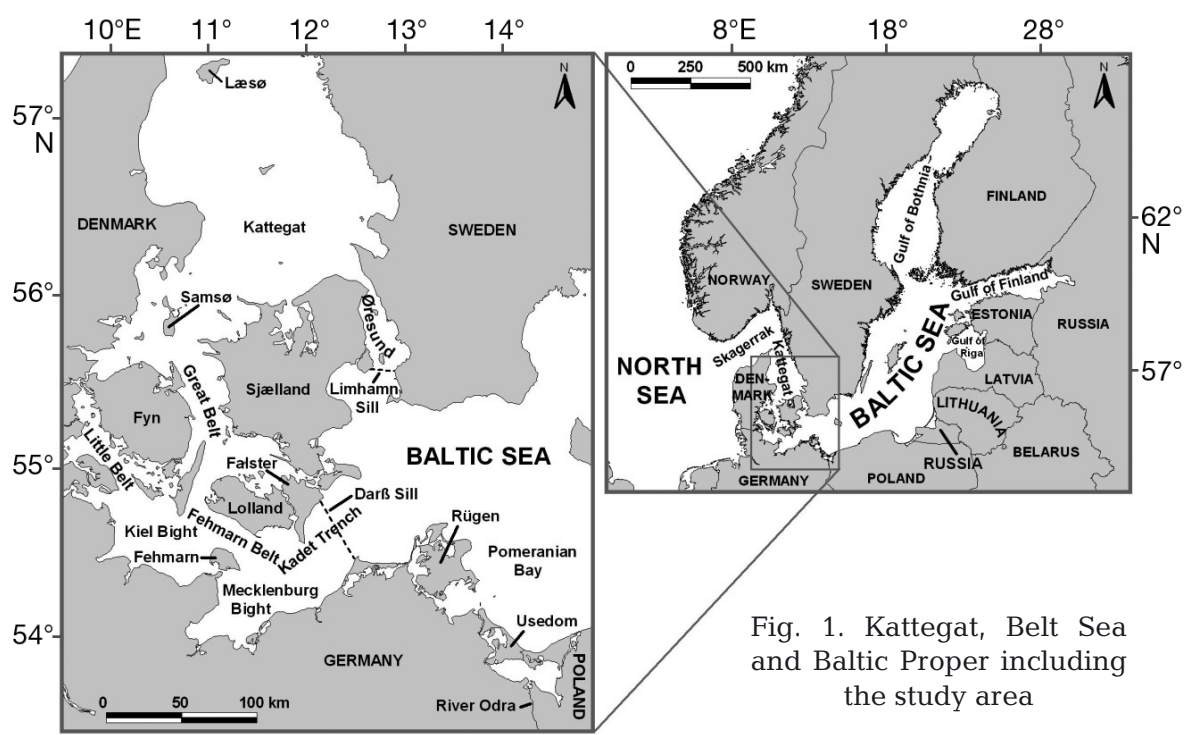




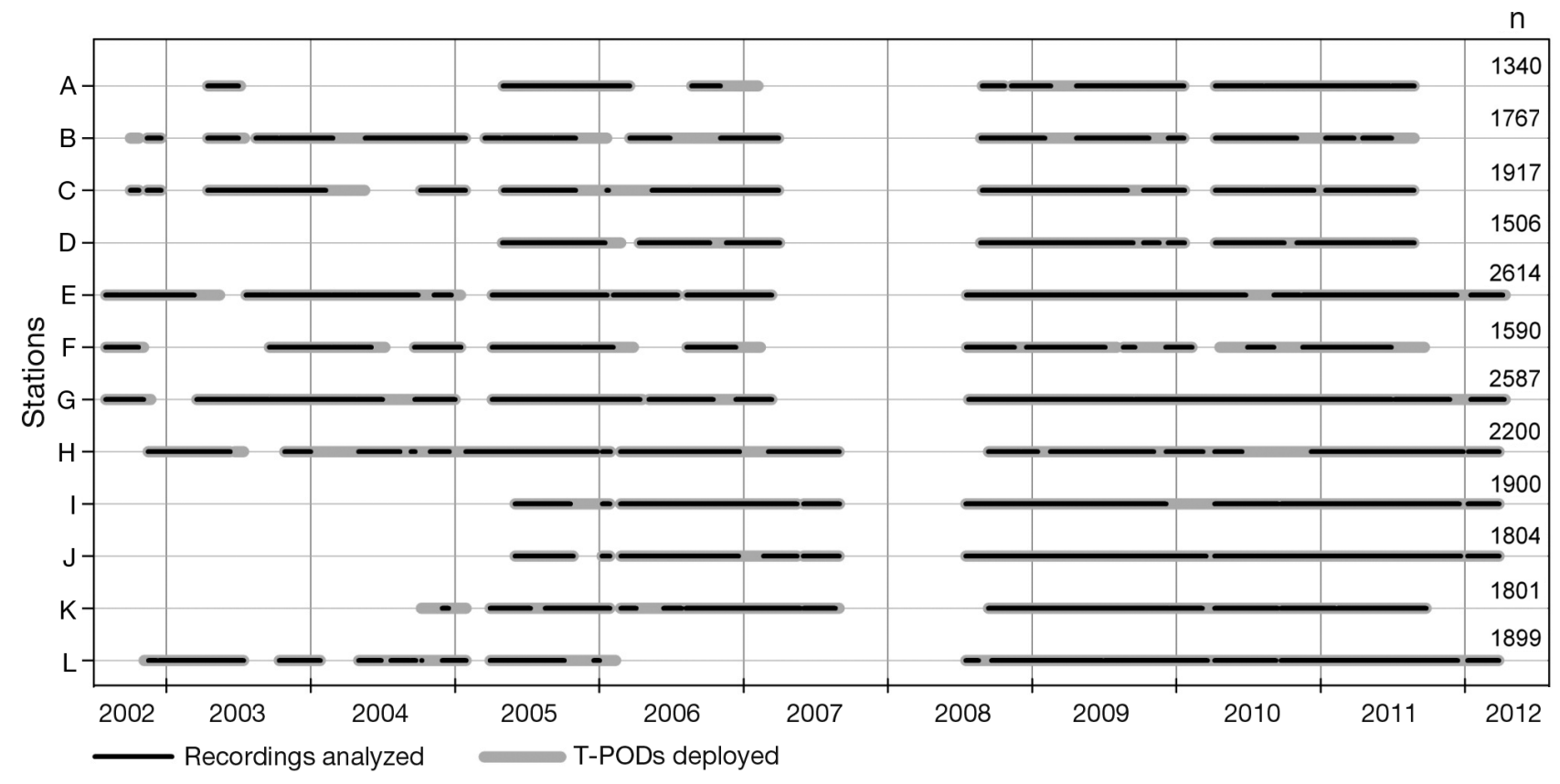

Fig. 2. Temporal distribution of recording effort at the 12 long-term click detector stations (see Fig. 3 for locations) in the German Baltic Sea, 2002 to 2012 ( $\mathrm{n}=$ no. of days recorded per station)

amounts to $21547 \mathrm{~km}^{3}$. The Baltic Sea consists of several sub-regions (Gulf of Bothnia, Gulf of Finland, Gulf of Riga, Baltic Proper, Belt Sea, and Kattegat) and is almost completely enclosed, with only a narrow opening to the North Atlantic via the North Sea at its western end. The surface salinity of the Baltic Sea declines from 20 PSU in the Kattegat to about 1 to 2 PSU in the Bothnian Bay and in the Gulf of Finland. Below a halocline at a depth of 60 to $80 \mathrm{~m}$, the Baltic Sea is frequently anoxic due to the heavy nutrient burden in the runoff from the large drainage area that intensifies eutrophication and accelerates oxygen depletion. Westerly storms are only infrequently able to push oxygenated salt water across shallow sills into the Baltic Proper, which is why oxygen depletion has become a serious problem for the Baltic Sea (see HELCOM 2003 for additional information on the environmental status of the Baltic Sea).

\section{Static acoustic monitoring with T-PODs}

The German Oceanographic Museum has been conducting static acoustic monitoring of harbour porpoises in the German Baltic Sea since 2002, using an array of up to 42 stations equipped with T-PODs (cf. Verfuß et al. 2007, 2008 for more details). Here, we present data from 12 stations that were installed as part of a monitoring programme and operated for 10 yr from 2002 to 2012 (Fig. 2). These 12 POD stations are grouped geographically into 3 areas (Fig. 3): the island of Fehmarn and the Mecklenburg Bight (4 stations; approx. $54^{\circ} 30^{\prime} \mathrm{N}, 11^{\circ} 20^{\prime} \mathrm{E}$ ) in the west, Kadet Trench (3 stations; approx. $54^{\circ} 30^{\prime} \mathrm{N}, 12^{\circ} 10^{\prime} \mathrm{E}$ ) centrally, and the Pomeranian Bay (5 stations; approx. $54^{\circ} 30^{\prime} \mathrm{N}, 14^{\circ} 20^{\prime} \mathrm{E}$ ) in the east. Data were processed and visually screened as described by Gallus et al. (2012) to eliminate false positives. Between 2002 and 2007, T-POD versions 2 to 5 were deployed. After 2007, only versions 4 and 5 were used to reduce any variation induced by hardware version. The instruments were calibrated annually in a test tank before and after data acquisition as described by Verfuß et al. (2013) to determine detection thresholds.

Since February 2005, the calibration included a procedure to adjust the detection thresholds before deployment as described in more detail by Verfuß et al. (2013). Since then, almost all T-PODs were preset to a standard detection threshold of $124 \mathrm{~dB}$ re $1 \mu \mathrm{Pa}$ (peak-peak) to ensure data comparability. Older T-PODs (version 2 and some version 3), however, could not be set to this standard detection threshold (Verfuß et al. 2013). Those T-PODs as well as T-PODs deployed at sea before February 2005 ranged in detection threshold from 114 to $143 \mathrm{~dB}$ re $1 \mu \mathrm{Pa}$ (peakpeak). Since the detection threshold influences the detection rate (Kyhn et al. 2008), this parameter was included into the statistical analysis as described in the next subsection. Furthermore, instruments were rotated among stations. Days with at least 1 visually 


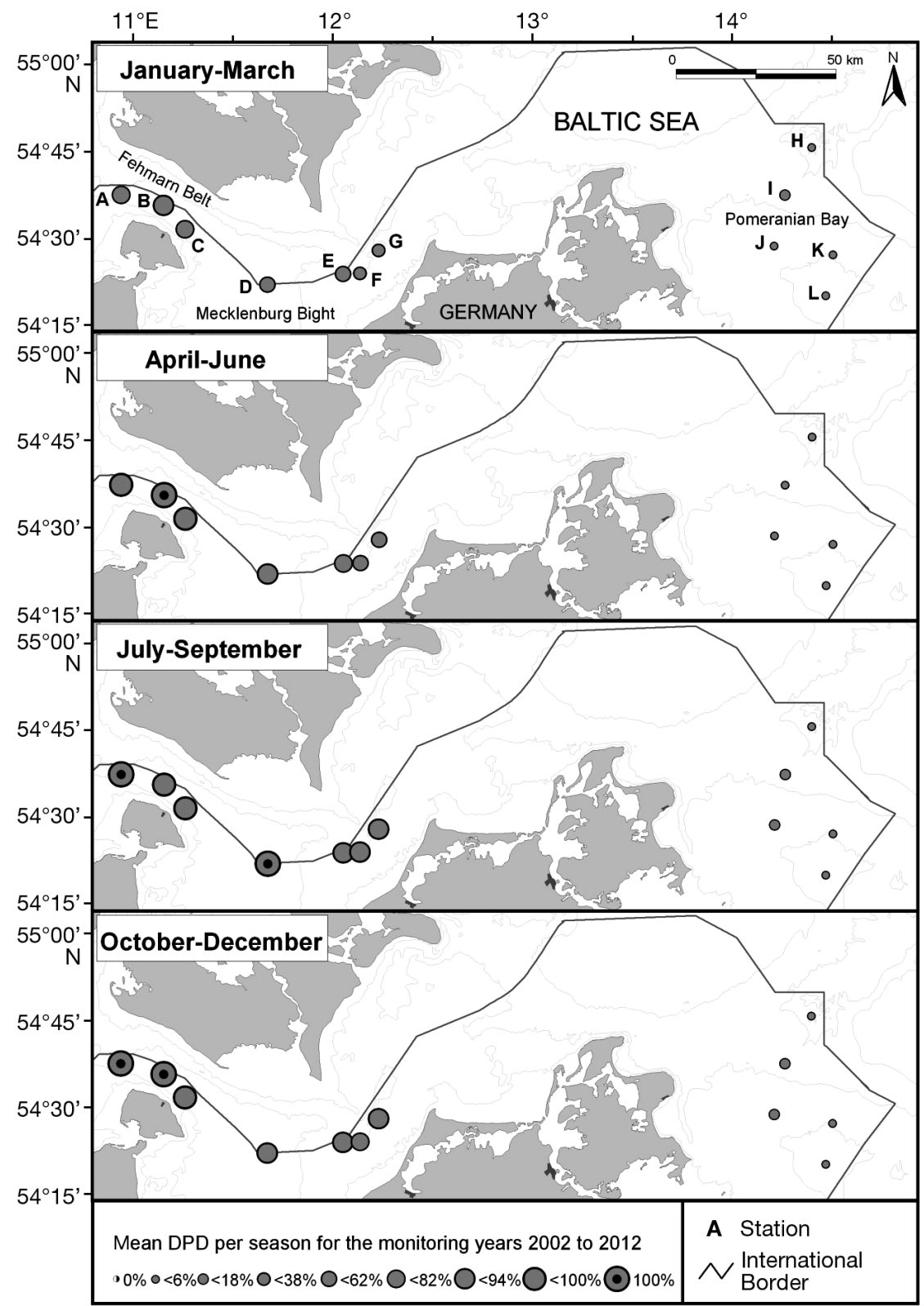

Fig. 3. Seasonal and geographical changes in harbour porpoise density indicated as proportion of detection-positive days (DPD) for a 3 month period (seasons), averaged over the years 2002 to 2012 (for sample sizes see Fig. 2)

confirmed porpoise detection were defined as DPDs. For additional details on instrument deployment and data analysis, see Verfuß et al. $(2007,2008)$ and Gallus et al. (2012).

\section{Modeling and statistical analysis}

We used a Generalized Additive Mixed Model (GAMM; Lin \& Zhang 1999, Wood 2006) run in R 2.15.1 (R Development Core Team 2012) with the library 'mgcv' (Wood 2011) to model seasonal variation for the different deployment groups and water depth as factor. DPD $\mathrm{mo}^{-1}$ was included as dependent variable in relation to thin plate smoothers of year (number of knots limited to 5) and month (as a cyclic smoother) as independent variables both grouped by the 3 areas Fehmarn/Mecklenburg Bight, Kadet Trench and Pomeranian Bay. Latitude and longitude were incorporated as tensor products (Wood 2006). T-POD version was included as random factor to account for differences between the hardware versions, and detection threshold as a random thin plate smoother (number of knots limited to 3) to account for differences in sensitivity of the hydrophones. A negative binomial distribution with theta $=0.5$ using a log-link was fitted to account for the limitation of reaching $100 \%$ DPD $\mathrm{mo}^{-1}$ in the Fehmarn/Mecklenburg Bight area. A backward selection was performed to remove variables not significantly influencing the model outcome. The model outcome was validated using residual and qqplots, (partial) autocorrelation plots and checked for overdispersion.

\section{RESULTS}

\section{Statistical model}

Water depth and detection threshold did not significantly influence the model outcome, and thus were removed. For the area Fehmarn/ Mecklenburg Bight, neither year nor month influenced the data significantly, while both of these variables significantly influenced DPD $\mathrm{mo}^{-1}$ in the areas Kadet Trench and Pomeranian Bay (Table 4). Spatial distribution as well as year (for Pomeranian Bay) influenced the model outcome most, as indicated by high $F$-values. The smoothing spline of month (Fig. 5) shows a distinct difference between the seasonal change in DPD $\mathrm{mo}^{-1}$ of the Kadet Trench (with a single maximum around August/September) and Pomeranian Bay (2 maxima around February and in 
Table 4. Results of the Generalized Additive Mixed Model (GAMM) of seasonal variation of Phocoena phocoena detections; adjusted $\mathrm{R}^{2}=0.83$, scale estimate $=0.79, \mathrm{n}=563 ;$ te $=$ tensor product, $\mathrm{s}=$ smoother

\begin{tabular}{|lcrr|} 
& Estimated df & $F$ & \multicolumn{1}{c|}{$\mathrm{p}$} \\
\hline Intercept & 291.22 & 50.41 & $<0.001$ \\
te (Longitude, Latitude) & 6.04 & 143.05 & $<0.001$ \\
s (Month): Fehmarn/Mecklenburg Bight & $<0.01$ & 0 & 0.921 \\
s (Month): Kadet Trench & 2.92 & 2.71 & $<0.001$ \\
s (Month): Pomeranian Bay & 4.09 & 1.70 & 0.005 \\
s (Year): Fehmarn/Mecklenburg Bight & 1.00 & 0.12 & 0.725 \\
s (Year): Kadet Trench & 1.00 & 6.57 & 0.011 \\
s (Year): Pomeranian Bay & 1.00 & 40.15 & $<0.001$ \\
& & & \\
\hline
\end{tabular}

August). The model indicates a positive effect of year on porpoise registration rates in both areas (Kadet Trench and Pomeranian Bay), indicating a significant increase in porpoise registrations between 2002 and 2012.

\section{Distribution and densities}

The data presented here show that harbour porpoises occur in all German Baltic Sea waters between the island of Fehmarn and the German-Polish border, albeit in decreasing densities from west to east (Figs. 3 to 5). Their distribution is not uniform, with higher concentrations of porpoise detections around the island of Fehmarn and near the Kadet Trench. For the area around Fehmarn and in the Mecklenburg Bight, the detection rates of harbour porpoises ranged from 39 to $100 \% \mathrm{DPD} \mathrm{mo}^{-1}$ during the period 2002 to 2007 (mean $=90.5 \%$ for all 4 stations). Since mid-2008, at least $92 \%$ DPD mo ${ }^{-1}$ were observed continuously, except for February, March and April of 2011 (Fig. 4). Using the parameter DPD $\mathrm{mo}^{-1}$, seasonal variation can only be assumed to exist in this area as lower detection rates were registered in some winters.

Data obtained from the Kadet Trench reveal a seasonal variation of porpoise occurrence, with higher incidence of DPDs in summer than in winter (Figs. 4 \& 5). From 2004 to 2011, the mean annual detection rates for the months June to December ranged from 83 to $99 \%$ DPD $\mathrm{mo}^{-1}$ for these 3 stations. The Pomeranian Bay was identified as the area with the lowest porpoise detection rates, where values ranged only between 0 and $30 \% \mathrm{DPD} \mathrm{mo}^{-1}$ for the 5 stations (Fig. 4) — which frequently equates to single detections per station and month on average. From 2008 on, porpoises were logged almost monthly, whereas there was no year-round presence of harbour porpoises in the Pomeranian Bay between 2002 and 2007. In these first $5 \mathrm{yr}$, porpoises could not be detected in the Pomeranian Bay in 30 of 51 months, whereas only 3 of 45 months resulted in 0 DPD mo-1 between 2008 and 2011. The mean DPD $\mathrm{mo}^{-1}$ increased over the study years in the Kadet Trench area and in the Pomeranian Bay area (Fig. 5), but not in the Fehmarn and Mecklenburg Bight area.

\section{Seasonal movements}

Within the German distribution areas of the respective populations, we recorded a seasonal pattern in acoustic detection rates (Figs. 4 \& 5). The seasonal

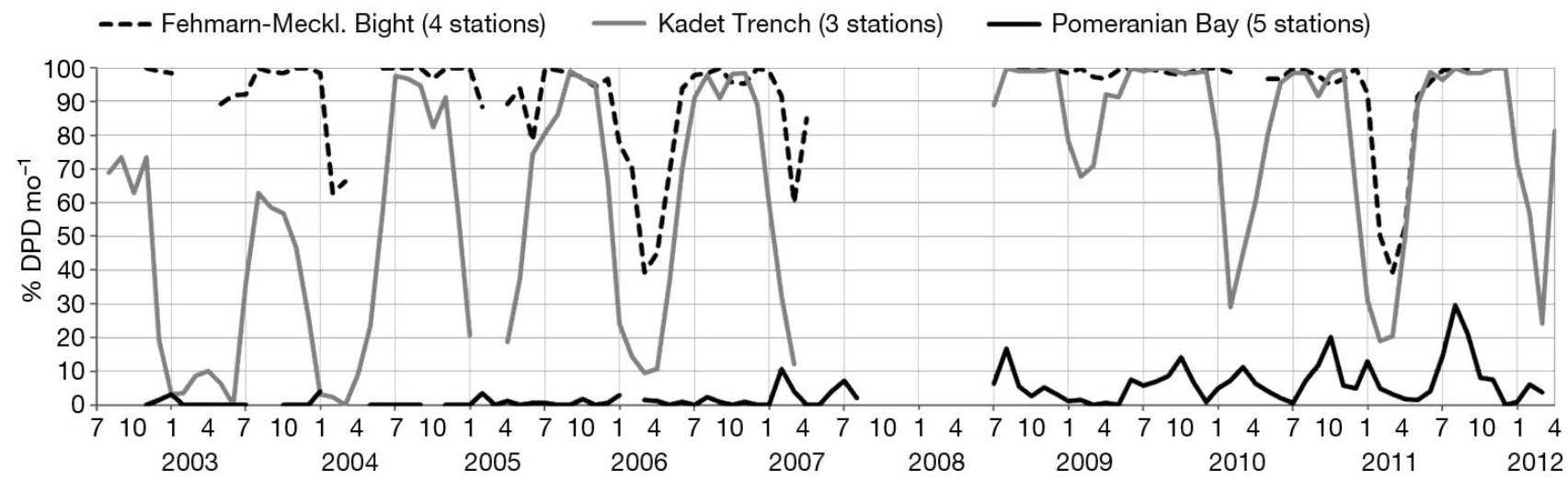

Fig. 4. Proportion of detection-positive days per month (DPD mo ${ }^{-1}$ ) for the areas Fehmarn/Mecklenburg Bight, Kadet Trench, and Pomeranian Bay from west to east along the German Baltic Sea coast. $x$-axis: month and year 

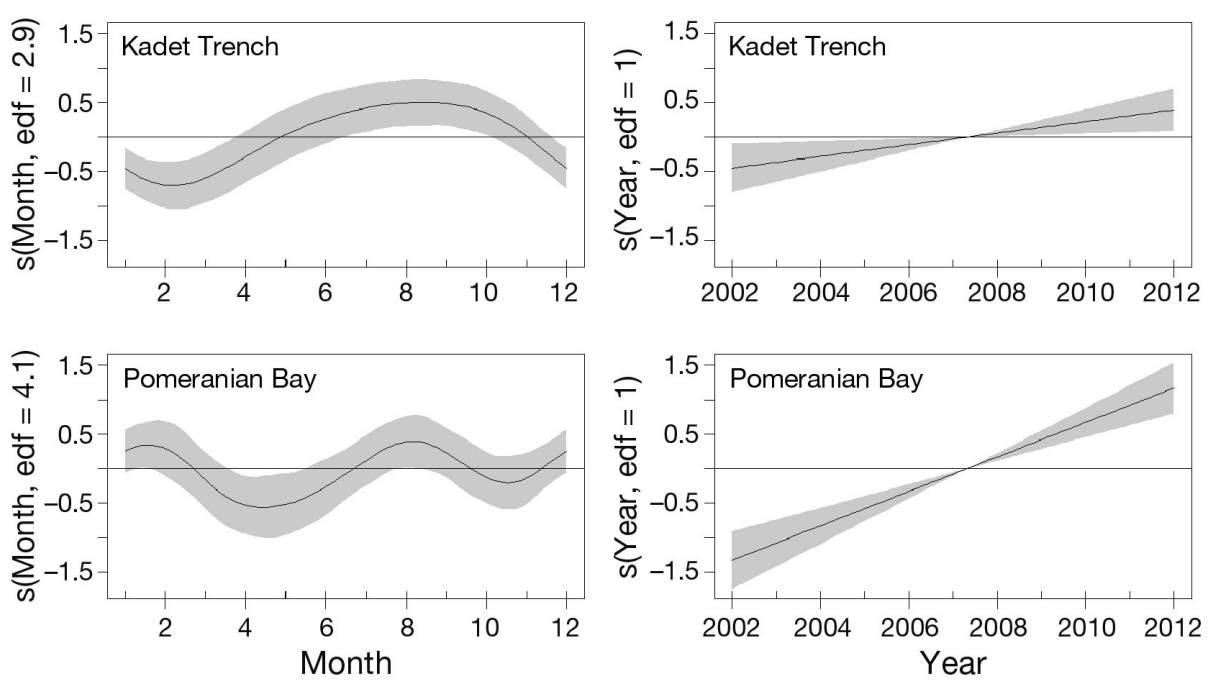

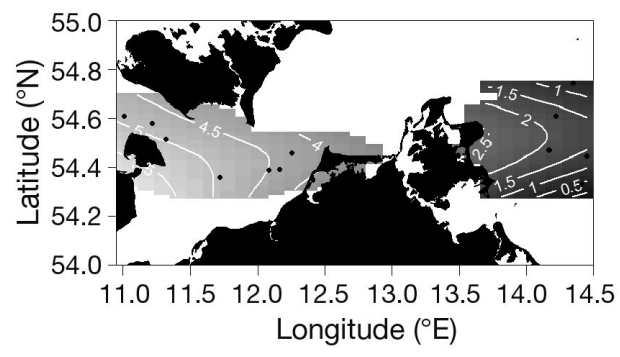

Fig. 5. General Additive Mixed Model (GAMM)-smoothers for significant co-variables when modelling distribution, seasonal patterns and annual differences of the detection positive days per month (DPD $\mathrm{mo}^{-1}$ ) for the areas Kadet Trench and Pomeranian Bay. Dots in the upper right graph represent the monitoring positions. edf $=$ estimated degrees of freedom; $\mathrm{s}=\mathrm{smoother}$. The contour plot shows the log-scaled (link) dependency of DPD mo $\mathrm{mor}^{-1}$ for the tensor product of Latitude and Longitude with decreasing impact from light to dark colours indicating higher densities in westerly waters

maxima in the proportion of DPD, particularly in late summer to early autumn and/or late winter to early spring depended on the geographic location of the stations. The 3 T-POD stations in the Kadet Trench showed a seasonal maximum proportion of DPD between June and November and a winter minimum from January to April (Fig. 4), resulting in a modelled maximum in August and a modelled minimum in February (Fig. 5). Less pronounced, this pattern can also be found for the 4 stations in the west around the island of Fehmarn and in Mecklenburg Bight, but the saturation of porpoise detections at $100 \% \mathrm{DPD}^{-1}$ only allows the identification of the winter minimum; the seasonal pattern could not be confirmed statistically.

Data from the 5 stations in the Pomeranian Bay show distinct winter maxima between January and March in addition to the summer/autumn maximum between July and November (Fig. 4). In the model, this resulted in 2 annual minima in April/May and October/November as well as 2 annual maxima in January/February and August (Fig. 5). The winter maximum has been visible in almost all years, whereas the summer maximum only became prominent after 2006 (Fig. 4).

\section{DISCUSSION}

Visual and acoustic monitoring survey efforts have revealed consistent distribution patterns for harbour porpoises in the Baltic Sea, with highest densities in the west and lowest in the east (Tables $2 \& 3$ ). Due to low porpoise densities in the Baltic Sea, acoustic monitoring appears to be the most effective method of detecting changes in harbour porpoise distribution, as it can be used continuously, and under adverse weather conditions. In the near future, static acoustic monitoring is also expected to provide information on actual abundances of harbor porpoises in low-density areas such as the Baltic Sea.

\section{Methodological constraints and recommendations}

The choice of using DPD $\mathrm{mo}^{-1}$ as the relevant unit limits the explanatory power for the western area of Fehmarn Belt/Mecklenburg Bight as well as Kadet Trench to some degree. Reaching $100 \%$ saturation in DPD $\mathrm{mo}^{-1}$ may conceal any potential seasonal pattern or interannual trends for the Fehmarn Belt/ Mecklenburg Bight area. It also explains the apparent leveling of Kadet Trench summer data in recent years as detections become saturated, while the summer registration rates in Pomeranian Bay continue to increase (see Fig. 5). On the other hand, 'proportion of DPD $\mathrm{mo}^{-1}$ ' has proven to be a valuable tool to study seasonal movements and interannual changes in the border region of the 2 Baltic harbour porpoise populations with low detection rates. DPD $\mathrm{mo}^{-1}$ is a very coarse unit suitable for low-density areas as it has 2 major advantages: the $24 \mathrm{~h}$ basis reduces the 
number of zeros in the data set, while at the same time reducing the influence of variation among device sensitivities due to the coarse time scale.

Although the detection threshold did not significantly influence the results, it should be accounted for statistically - as we have done in the current study since the sensitivity of T-PODs inevitably influences the amount of data recorded (Kyhn et al. 2008). Furthermore, it is important to include information on the version or type of detector when using more than one version/type. This is of special importance as T-PODs were replaced by the successor, the C-POD, in 2009.

\section{Seasonal occurrence and trends in harbour porpoise presence}

Static acoustic monitoring and aerial surveys revealed temporal and geographical changes in harbour porpoise occurrence, highlighting decreasing porpoise detections from west to east (Table 2, Figs. 3 to 5). The strong decrease in harbour porpoise densities from the Inner Danish Waters (Belt Sea) to the Pomeranian Bay was recorded repeatedly during various aerial surveys (Gillespie et al. 2005, Siebert et al. 2006, Scheidat et al. 2008). The recurring seasonal pattern in porpoise presence (also shown by Verfuß et al. 2007, 2008, Gallus et al. 2012) was confirmed for a considerably longer period in the present study. Westward movements in winter into more saline waters possibly occur to avoid entrapment by sea ice (Verfuß et al. 2007, Gallus et al. 2012). Higher detection rates in summer compared to winter (Figs. 4 \& 5) also suggest the importance of the German part of the Baltic Sea as habitat for reproduction (as previously suggested by Verfuß et al. 2007), especially for the Belt Sea population. Within the study area, the 2 harbour porpoise populations show a seasonal variation in their apparent population densities expressed as seasonal variation in acoustic detection rates.

The westward movements of the Belt Sea and Baltic Proper populations during winter would explain the coincidence of the winter maximum in Pomeranian Bay (arrival of Baltic Proper animals) with the winter minimum in the Kadet Trench (departure of Belt Sea animals). The majority of the southern portion of the Belt Sea population appears to move from German into Danish waters, and (a portion of) the Baltic Proper population appears to congregate east of the island of Rügen off the mouth of the river Odra (Pomeranian Bay). Historically, the seasonal movements of the Belt Sea population formed the basis of an annual drive hunt in the western Belt Sea (Kinze 1995). On a smaller geographic scale, Sveegaard (2006) was able (with the use of T-PODs) to show a seasonal migration of wintering Belt Sea porpoises into and out of the Flensburg Fjord, at the northwestern Baltic border between Germany and Denmark.

When both populations expand eastward in spring and summer, the waters near the German-Polish border may be used to some degree by the farthest southeastern migrating individuals of the Belt Sea population. In that case, the same population would cause the summer maximum in the Pomeranian Bay and the coinciding summer maximum in the Kadet Trench (Fig. 5). The unique sighting of 84 individuals in 32 groups around the island of Rügen in July 2002 (Scheidat et al. 2008) appears to be an example of the summer immigration of Belt Sea porpoises. The Pomeranian Bay may thus harbour a spatial but not a temporal overlap of individuals of the 2 populations moving in synchrony (Fig. 6) as was also suggested by Gallus et al. (2012). The eastward movement appears to have developed over the years. In the early part of the study period, the summer maximum in the Kadet Trench peaked for 1 or 2 months, whereas $100 \%$ DPD $\mathrm{mo}^{-1}$ were registered for several months at a time in recent years, coinciding with a rise in summer maxima in the Pomeranian Bay over the years (Fig. 4). This development is indicated by the significant increase in DPD mo ${ }^{-1}$ with year in the Kadet Trench and the Pomeranian Bay (Fig. 5). This increase in registration rates does not necessarily reflect a population increase, however, but perhaps rather a change in site or habitat preference.

In the UK and eastern Canada, harbour porpoise distribution correlates with prey distribution, frontal zones, water depth and other environmental variables (Santos et al. 2004, Johnston et al. 2005, Goodwin 2008, Bailey \& Thompson 2009, Isojunno et al. 2012). The importance of environmental factors such as currents, chlorophyll and nutrients was also confirmed by Danish and German studies (Edrén et al. 2010, Gilles et al. 2011, Sveegaard et al. 2012a,b). In the Belt Sea and Kattegat, the geographic distribution of porpoise concentrations appeared fairly stable when acoustic detection rates provided a pattern similar to the distribution of satellite-tagged animals averaged over 10 yr (Sveegaard et al. 2011b).

In autumn and winter, seasonal changes in harbour porpoise distribution are particularly difficult to detect visually due to weather constraints, as rough seas limit sightability. Only 2 previous studies of satellite-tagged harbour porpoises were able to 
show seasonal movements, possibly also linked to changes in prey distribution (Read \& Westgate 1997, Sveegaard et al. 2012a). Sveegaard et al. (2011a, p. 241-242) emphasized, however, that the observed seasonal movement patterns were not temporally coordinated migrations, but rather 'a seasonal change in importance of some [...] areas' and 'a gradual overall movement over a longer period'. Furthermore, their findings correlated with the results of Read \& Westgate (1997), who satellite-tracked 9 harbour porpoises in the Bay of Fundy and Gulf of Maine, Canada, and detected seasonal changes in distribution, but these changes were individually discrete and gradual. Sveegaard et al. (2011a) found significant southward movements of animals into the Inner Danish Waters from spring to winter, which allows porpoises to avoid the Kattegat area in winter. Therefore, it appears that the Belt Sea population contracts seasonally southward at its northern range (Sveegaard et al. 2011a) and northward at its southern range (this study) resulting in a situation that poses numerous conservation challenges.

To summarize the findings obtained from harbour porpoise surveys in the Baltic Sea (Table 2), reliable abundance estimates have only been derived from the western part (i.e. the Belt Sea); all studies aiming at producing estimates for the area east of the Darss Sill and around the island of Rügen resulted in uncertain abundance estimates due to very low sample sizes (e.g. Berggren et al. 2004). With our long-term data set, we were able to confirm previous findings of a decreasing harbour porpoise presence towards the Baltic Proper. Over the last few years, however, an increase of porpoise detections was noted in the Pomeranian Bay - especially during summer - suggesting an eastward extension of the Belt Sea population's summer distribution.

\section{Status of the two populations}

The conservation status of both the Belt Sea and the Baltic Proper population has to be considered as continuously critical. The Baltic Proper population has not yet recovered since its IUCN red-listing designation of 'Critically Endangered' (Hammond et al. 2008), while recent surveys of the Belt Sea population suggest a severe decline in less than 2 decades (Sveegaard et al. 2013). In the German part of the Belt Sea, such an appraisal is supported by a bycatch rate assessment (Scheidat et al. 2008) that showed annual bycatch rates exceeding $1.7 \%$ of the current porpoise population (i.e. the proportion of a healthy population

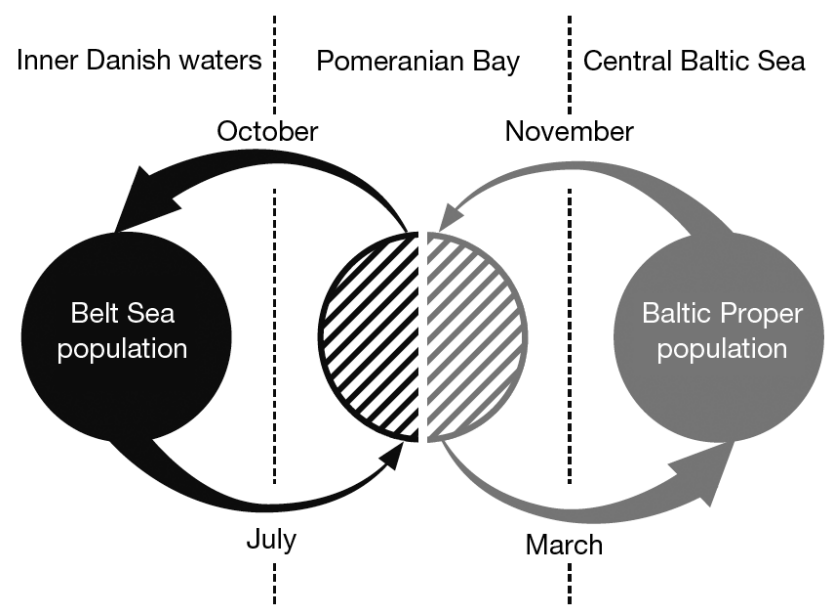

Fig. 6. Schematic representation of likely seasonal habitat use of the boundary waters by the 2 harbour porpoise populations of the Baltic Sea. Note that the months indicated represent mean values over the study period (see Fig. 5)

that constitutes the maximum total anthropogenic removal tolerable per annum according to an international agreement; ASCOBANS 2000).

Although an abundance estimate for the harbour porpoise population of the Baltic Proper using only static acoustic monitoring may not yet be possible, acoustic monitoring is the only practicable method to assess its status. The Static Acoustic Monitoring of the Baltic Sea Harbour Porpoise (SAMBAH) project is aiming to apply methods used in distance sampling to static acoustic monitoring in order to estimate abundances of harbour porpoises in the Baltic Proper. Since the number of harbour porpoises in the Baltic Proper has declined to a point where visual methods to estimate population size (such as line transect methods) are no longer deemed effective, static acoustic monitoring was chosen as a cost-efficient alternative for monitoring echolocating harbour porpoises in low-density areas. Further SAMBAH project goals are to generate modelled distribution maps and identify areas of high concentration and important habitats, and to define areas with a high risk of conflict with human activities (www.sambah.org).

\section{Conservation actions and conservation needs}

The main threats to the Baltic Sea harbour porpoise are primarily unintended bycatch in passive fisheries, emission of underwater noise and chemical pollution (e.g. Koschinski 2001, ASCOBANS 2002, 2009 and references therein). Various national and international agreements and regulations have been adopted containing both general and specific objec- 
tives on the protection of the Baltic Sea harbour porpoise (e.g. ASCOBANS 2002, 2009, 2012 as well as national conservation plans such as Carlström et al. 2008).

The Helsinki Convention for the protection of the marine environment of the Baltic Sea area offers protection to Baltic Sea harbour porpoises, e.g. by HELCOM Recommendation 17/2. Contracting Parties are required to give highest priority to the avoidance of harbour porpoise bycatch, to collect and analyze data on population distribution and abundance, stock identities and threats such as pollutant levels, bycatch mortality, disturbance by shipping (e.g. underwater noise), and to consider the establishment of marine protected areas for harbour porpoises within the framework of the Baltic Sea Protected Areas (HELCOM 1996).

HELCOM's Baltic Sea Action Plan (BSAP, adopted in November 2007) aims to increase the knowledge about and protection of Baltic Sea marine habitats and species by further developing a coordinated reporting system and database on Baltic harbour porpoise sightings, bycatches and strandings in collaboration with ASCOBANS. Furthermore, the plan aims to promote research which develops additional methods for the assessment of, and reporting on, the impacts of fisheries on biodiversity. On an EU level, the European Council took action in April 2004 to mitigate the bycatch of marine mammals in EU waters by adopting a regulation on the use of acoustic deterrent devices (also known as pingers) and on bycatch observer schemes (European Council 2004). In practice, however, an effective harbour porpoise protection is compromised due to the regulation's restriction to selected fisheries and vessel sizes, its geographically patchy application and due to a severe lack of national enforcement. There is no indication that the measures taken so far had any positive effects for the critically endangered Baltic Sea harbour porpoise.

In 2008, the EU Marine Strategy Framework Directive (MSFD) came into force, requiring member states of the EU to achieve 'good environmental status' (GES) for their marine waters by 2020. Their determination of GES shall, according to the directive, take into account the characteristics of pressures and impacts on their marine waters such as incidental non-target catches and underwater noise (European Council 2008). By 2015, all EU member states are to develop programmes of measures designed to achieve or maintain GES. Therefore, an implementation by member states bordering the Baltic Sea can only comply with EU requirements if their national marine strategies contain clear and practicable measures with timely targeted implementation programmes in order to achieve GES. With regard to the harbour porpoise, this means that the national programmes of protective measures should significantly reduce the impacts of bycatch and underwater noise in their marine waters. Member states would thereby meet the requirements of the MSFD and at the same time eventually fulfil the other existing regulations and international agreements mentioned in this section.

\section{CONCLUSION}

Besides the toxic burden of persistent organic pollutants that likely reduced reproductive success (Berggren et al. 1999, Bruhn et al. 1999, Beineke et al. 2005), the impact of bycatch on the harbour porpoise populations in the Baltic Sea is believed to have a huge and growing effect on population level. Protection of porpoises in the Baltic region urgently requires an effective restriction of gillnet fisheries. For the Belt Sea population, this appears to be particularly needed in high-density areas such as in the Kadet Trench and Fehmarn Belt as well as in parts of Kiel Bight and Flensburg Fjord (ASCOBANS 2012) even though porpoises are found throughout the German Baltic Sea and are protected under EU legislation in their entire distributional range. Management plans for marine protected areas as well as conservation plans for the species have to ban the use of static nets and specify steps to mitigate noise disturbance (also from deterrent devices) during times of high occurrence. For the survival of the Baltic Proper population, bycatch needs to be prevented immediately (Berggren et al. 2002) by replacing gillnets in the whole area with alternative fishing gears such as fish traps (ASCOBANS 2002, 2009), since the use of acoustic harrassment devices may not prevent bycatch sufficiently and may keep porpoises out of their preferred feeding grounds.

Acknowledgements. The success of long-term research usually relies on the support of numerous individuals and we are grateful to I. Baresel, H. Bentzien, H. Charwat, T. Förster, I. Giannikos, A. Herrmann, A. Kilian, M. Klehm, A. Krutwa, P. Leopold, S. Osterrieder, J. Subklew, I. Thomas, D. Tode, and N. Tregenza for their help. We are indebted to the Federal Maritime and Hydrographic Agency, the Coastguard Service, the Federal Border Guard, the Water and Shipping Authorities in Stralsund and Lübeck as well as the crews of RV 'Seefuchs' and RV 'Palaemon' for administrative help, continuous cooperation and safe transport at sea. T. Korth helped with the design of Fig. 6. S. Sveegaard, 
N. J. C. Tregenza, J. Wood and 2 anonymous reviewers provided valuable suggestions and constructive criticism that improved the manuscript. Funding was provided by the German Federal Agency for Nature Conservation (BfN) and the German Ministry for Environment, Nature Conservation and Nuclear Safety (BMU).

\section{LITERATURE CITED}

Andersen SH (1974) A typical case history of the net-caught harbour porpoise, Phocoena phocoena, from Danish waters. Aquat Mamm 2:1-6

Andersen SH (1982) Change in occurrence of the harbour porpoise, Phocoena phocoena, in Danish waters as illustrated by catch statistics from 1834 to 1970 . Mammals in the seas, Vol 4: small cetaceans, seals, sirenians and otters. FAO Fish Ser 5:131-133

Andersen SH, Rebsdorff A (1976) Polychlorinated hydrocarbons and heavy metals in harbour porpoise (Phocoena phocoena) and whitebeaked dolphin (Lagenorhynchus albirostris) from Danish waters. Aquat Mamm 4:14-20

ASCOBANS (Agreement on the Conservation of Small Cetaceans of the Baltic and North Seas) (2000) Resolution no. 3: incidental take of small cetaceans. 3rd session of the meeting of parties, Bristol, UK 26-28 July 2000. Available at www.ascobans.org/pdf/mops/MOP3_20003_IncidentalTake.pdf (accessed 15 June 2013)

ASCOBANS (2002) ASCOBANS Recovery Plan for Baltic Harbour Porpoises (Jastarnia Plan). Available at www. bfn.de/fileadmin/MDB/documents/themen/artenschutz/ pdf/Jastarnia_Plan.pdf

ASCOBANS (2009) ASCOBANS Recovery Plan for Baltic Harbour Porpoises-Jastarnia Plan (2009 Revision). Available at www.ascobans.org/pdf/ASCOBANS_JastarniaPlan_MOP6.pdf (accessed 15 June 2013)

ASCOBANS (2012) Conservation Plan for the Harbour Porpoise Population in the Western Baltic, the Belt Sea and the Kattegat. Available at www.ascobans.org/ pdf/HarbourPorpoise_ConservationPlan_WesternBaltic_ MOP7_2012.pdf (accessed 15 June 2013)

Bailey H, Thompson PM (2009) Using marine mammal habitat modeling to identify priority conservation zones within a marine protected area. Mar Ecol Prog Ser 378: 279-287

Beineke A, Siebert U, McLachlan M, Bruhn R and others (2005) Investigations of the potential influence of environmental contaminants on the thymus and spleen of harbour porpoises (Phocoena phocoena). Environ Sci Technol 39:3933-3938

Benke H (1994) A note on cetacean bycatches in German waters. Rep Int Whaling Comm 15(Spec Issue):217-218

Berggren P (1994) Bycatches of the harbour porpoise (Phocoena phocoena) in the Swedish Skagerrak, Kattegat and Baltic Seas, 1973-1993. Rep Int Whaling Comm 15(Spec Issue):211-215

Berggren P, Ishaq R, Zebuhr Y, Näf C, Bandh C, Broman D (1999) Patterns and levels of organochlorine contaminants (DDTs, PCBs, non-ortho PCBs and PCDD/Fs) in male harbour porpoises (Phocoena phocoena) from the Baltic Sea, the Kattegat-Skagerrak Seas and the West Coast of Norway. Mar Pollut Bull 38:1070-1084

Berggren P, Wade PR, Carlström J, Read AJ (2002) Potential limits to anthropogenic mortality for harbour porpoises in the Baltic region. Biol Conserv 103:313-322
Berggren P, Hiby L, Lovell P, Scheidat M (2004) Abundance of harbour porpoises in the Baltic Sea from aerial surveys conducted in summer 2002. Paper SC/56/SM7 presented to the IWC Scientific Committee, July 2004, Sorrento

$>$ Börjesson P, Read AJ (2003) Variation in timing of conception between populations of the harbor porpoise. J Mammal 84:948-955

> Bruhn R, Kannan N, Petrick G, Schulz-Bull DE, Duinker JC (1999) Persistant chlorinated organic contaminants in harbour porpoises from the North Sea, the Baltic Sea and Arctic waters. Sci Total Environ 237-238:351-361

Carlström J, Rappe C, Königson S (2008) Åtgärdsprogram för tumlare 2008-2013 (Phocoena phocoena). Naturvårdsverket rapport 5846, Naturvårdsverket, Stockholm

Clausen B, Andersen S (1988) Evaluation of bycatch and health status of the harbour porpoise (Phocoena phocoena) in Danish waters. Dan Rev Game Biol 13:2-20

Cooke JG (1984) The relationship between the Net Catcher Day and the Gross Catcher Day as a unit of effort. Rep Int Whaling Comm 34:288-290

Edrén SMC, Wisz MS, Teilmann J, Dietz R, Söderkvist J (2010) Modelling spatial patterns in harbour porpoise satellite telemetry data using maximum entropy. Ecography 33:698-708

European Council (1992) Council Directive 92/43/EEC of 21 May 1992 on the conservation of natural habitats and of wild fauna and flora. Off J Eur Union L 206:7-50

European Council (2004) Council Regulation (EC) No 812/2004 of 26.4.2004 laying down measures concerning incidental catches of cetaceans in fisheries and amending Regulation (EC) No 88/98. Off J Eur Union L 150: 12-31

European Council (2008) Directive 2008/56/EC of the European Parliament and of the Council of 17 June 2008 establishing a framework for community action in the field of marine environmental policy (Marine Strategy Framework Directive). Off J Eur Union L 164:19-40

> Evans PGH, Hammond PS (2004) Monitoring cetaceans in European waters. Mammal Rev 34:131-156

> Falandysz J, Yamashita N, Tanabe S, Tatsukawa R, Rucinska L, Skora K (1994) Congener-specific data on polychlorinated biphenyls in tissues of common porpoise from Puck Bay, Baltic Sea. Arch Environ Contam Toxicol $26: 267-272$

> Galatius A, Kinze CC, Teilmann J (2012) Population structure of harbour porpoises in the greater Baltic region: evidence of separation based on geometric morphometric comparisons. J Mar Biol Assoc UK 92:1669-1676

Gallus A, Dähne M, Verfuß UK, Bräger S, Adler S, Siebert U, Benke H (2012) Use of passive acoustic monitoring to assess the status of the 'Critically Endangered' Baltic harbour porpoise in German Waters. Endang Species Res 18:265-278

Gerrodette T, Taylor BL, Swift R, Rankin S, Jaramillo-Legorreta AM, Rojas-Bracho L (2011) A combined visual and acoustic estimate of 2008 abundance, and change in abundance since 1997, for the vaquita, Phocoena sinus. Mar Mamm Sci 27:E79-E100

Gilles A, Adler S, Kaschner K, Scheidat M, Siebert U (2011) Modelling harbour porpoise seasonal density as a function of the German Bight environment: implications for management. Endang Species Res 14:157-169

Gillespie D, Berggren P, Brown S, Kuklik I and others (2005) Relative abundance of harbour porpoises (Phocoena phocoena) from acoustic and visual surveys of the Baltic 
Sea and adjacent waters during 2001 and 2002. J Cetacean Res Manag 7:51-57

- Goodwin L (2008) Diurnal and tidal variations in habitat use of the harbour porpoise (Phocoena phocoena) in Southwest Britain. Aquat Mamm 34:44-53

Granby K, Kinze CC (1991) Organochlorines in Danish and West Greenland harbour porpoises. Mar Pollut Bull 22: 458-462

Hammond PS, Berggren P, Benke H, Borchers DL and others (2002) Abundance of harbour porpoises and other cetaceans in the North Sea and adjacent waters. J Appl Ecol 39:361-376

Hammond PS, Bearzi G, Bjørge A, Forney K and others (2008) Phocoena phocoena (Baltic Sea subpopulation). IUCN Red List of Threatened Species. Available at www.iucnredlist.org (accessed 15 June 2013)

> Hammond PS, Macleod K, Berggren P, Borchers DL and others (2013) Cetacean abundance and distribution in European Atlantic shelf waters to inform conservation and management. Biol Conserv 164:107-122

> Heide-Jørgensen MP, Mosbech A, Teilmann J, Benke H, Schultz W (1992) Harbor porpoise (Phocoena phocoena) densities obtained from aerial surveys north of Fyn and in the Bay of Kiel. Ophelia 35:133-146

Heide-Jørgensen MP, Teilmann J, Benke H, Wulf J (1993) Abundance and distribution of harbour porpoises, Phocoena phocoena, in selected areas of the western Baltic and the North Sea. Helgol Meeresunters 47:335-346

HELCOM (1996) Protection of harbour porpoise in the Baltic Sea area. HELCOM Recommendation 17/2. Available at www.helcom.fi/Recommendations/en_GB/rec17_2/ (accessed 15 June 2013)

HELCOM (2003) The Baltic marine environment, 19992002. Balt Sea Environ Proc 87:1-46

> Huggenberger S, Benke H, Kinze CC (2002) Geographical variation in harbour porpoise (Phocoena phocoena) skulls: support for a separate non-migratory population in the Baltic Proper. Ophelia 56:1-12

Isojunno S, Matthiopoulos J, Evans PGH (2012) Harbour porpoise habitat preferences: robust spatio-temporal inferences from opportunistic data. Mar Ecol Prog Ser 448:155-170

> Johnston DW, Westgate AJ, Read AJ (2005) Effects of finescale oceanographic features on the distribution and movements of harbour porpoises Phocoena phocoena in the Bay of Fundy. Mar Ecol Prog Ser 295:279-293

Kannan K, Falandysz J, Tanabe S, Tatsukawa R (1993) Persistent organochlorines in harbour porpoises from Puck Bay, Poland. Mar Pollut Bull 26:162-165

Kinze CC (1995) Exploitation of harbour porpoises (Phocoena phocoena) in Danish waters: a historical review. In: Bjørge A, Donovan GP (eds) Biology of the Phocoenids. Rep Int Whaling Comm 16(Spec Issue):141-153

Koschinski S (2001) Current knowledge on harbour porpoises (Phocoena phocoena) in the Baltic Sea. Ophelia 55:167-197

Kyhn LA, Tougaard J, Teilmann J, Wahlberg M, Jørgensen PB, Bech NI (2008) Harbour porpoise (Phocoena phocoena) static acoustic monitoring: laboratory detection thresholds of T-PODs are reflected in field sensitivity. J Mar Biol Assoc UK 88:1085-1091

Kyhn LA, Tougaard J, Thomas L, Rosager Duve L and others (2012) From echolocation clicks to animal densityacoustic sampling of harbor porpoises with static dataloggers. J Acoust Soc Am 131:550-560
Leeney RH, Carslake D, Elwen SH (2011) Using static acoustic monitoring to describe echolocation behaviour of Heaviside's dolphins (Cephalorhynchus heavisidii) in Namibia. Aquat Mamm 37:151-160

> Lin X, Zhang D (1999) Inference in generalized additive mixed models by using smoothing splines. J R Stat Soc B 61:381-400

Loos P, Cooke J, Deimer P, Fietz K, Hennig V, Schütte HJ (2010) Opportunistic sightings of harbour porpoises (Phocoena phocoena) in the Baltic Sea at large-Kattegat, Belt Sea, Sound, Western Baltic and Baltic Proper. ASCOBANS Document AC17/Doc.5-05. Available at www. ascobans.org/pdf/ac17/AC17_5-05_rev1_Opportunistic SightingsHarbourPorpoisesBalticSea.pdf (accessed 6 June 2013)

Mellinger DK, Staford KM, Moore SE, Dziak RP, Matsumoto $\mathrm{H}$ (2007) An overview of fixed passive acoustic monitoring methods for cetaceans. Oceanography 20:36-45

R Development Core Team (2012) R: a language and environment for statistical computing. R Foundation for Statistical Computing, Vienna

> Rayment W, Dawson S, Slooten L (2009) Use of T-PODs for acoustic monitoring of Cephalorhynchus dolphins: a case study with Hector's dolphins in a marine protected area. Endang Species Res 10:333-339

Rayment W, Dawson S, Scali S, Slooten L (2011) Listening for a needle in a haystack: passive acoustic detection of dolphins at very low densities. Endang Species Res 14: 149-156

Read AJ, Westgate AJ (1997) Monitoring the movements of harbour porpoises (Phocoena phocoena) with satellite telemetry. Mar Biol 130:315-322

Santos MB, Pierce GJ, Learmonth JA, Reid RJ and others (2004) Variability in the diet of harbor porpoises (Phocoena phocoena) in Scottish waters 1992-2003. Mar Mamm Sci 20:1-27

Sasaki-Yamamoto Y, Akamatsu T, Ura T, Sugimatsu H and others (2013) Diel changes in the movement patterns of Ganges River dolphins monitored using stationed stereo acoustic data loggers. Mar Mamm Sci 29:589-605

Scheidat M, Gilles A, Kock KH, Siebert U (2008) Harbour porpoise Phocoena phocoena abundance in the southwestern Baltic Sea. Endang Species Res 5:215-223

Siebert U, Gilles A, Lucke K, Ludwig M, Benke H, Kock $\mathrm{KH}$, Scheidat M (2006) A decade of harbour porpoise occurrence in German waters - analysis of aerial surveys, incidental sightings and strandings. J Sea Res 56: $65-80$

Sveegaard S (2006) Selection of Special Areas of Conservation for harbour porpoises in Denmark. MSc thesis, University of Copenhagen

Sveegaard S, Teilmann J, Tougaard J, Dietz R, Mouritsen KN, Desportes G, Siebert U (2011a) High-density areas for harbour porpoises (Phocoena phocoena) identified by satellite tracking. Mar Mamm Sci 27:230-246

> Sveegaard S, Teilmann J, Berggren P, Mouritsen KN, Gillespie D, Tougaard J (2011b) Acoustic surveys confirm the high-density areas of harbour porpoises found by satellite tracking. ICES J Mar Sci 68:929-936

> Sveegaard S, Andreasen H, Mouritsen KN, Jeppesen JP, Teilmann J, Kinze CC (2012a) Correlation between the seasonal distribution of harbour porpoises and their prey in the Sound, Baltic Sea. Mar Biol 159:1029-1037

Sveegaard S, Nabe-Nielsen J, Stæhr KJ, Jensen TF, Mouritsen KN, Teilmann J (2012b) Spatial interactions between 
marine predators and their prey: herring abundance as a driver for the distributions of mackerel and harbour porpoise. Mar Ecol Prog Ser 468:245-253

Sveegaard S, Teilmann J, Galatius A (2013) Abundance survey of harbour porpoises in Kattegat, Belt Seas and the Western Baltic, July 2012. Danish Centre for Environment and Energy. Available at http://dce.au.dk/ fileadmin/dce.au.dk/Udgivelser/Abundance_survey_of_ harbour_porpoises_2012_20130612.pdf (accessed 15 June 2013)

Szefer P, Malinga M, Skóra K, Pempkowiak J (1994) Heavy metals in harbour porpoises from Puck Bay in the Baltic Sea. Mar Pollut Bull 28:570-571

Teilmann J (2003) Influence of sea state on density estimates of harbour porpoises (Phocoena phocoena). J Cetacean Res Manag 5:85-92

Teilmann J, Sveegaard S, Dietz R (2011) Status of a harbour porpoise population - evidence of population separation and declining abundance. In: Sveegaard S (ed) Spatial and temporal distribution of harbor porpoises in relation to their prey. $\mathrm{PhD}$ dissertation, Aarhus University, p 75-84 (available at www2.dmu. $\mathrm{dk} /$ pub/phd_sign.pdf)

Teilmann J, Christiansen CT, Kjellerup S, Dietz R, Nachman G (2013) Geographic, seasonal, and diurnal surface behavior of harbor porpoises. Mar Mamm Sci 29: E60-E76

Tiedemann R, Harder J, Gmeiner C, Haase E (1996) Mitochondrial DNA sequence patterns of harbour porpoises

Editorial responsibility: Peter Corkeron, Woods Hole, Massachusetts, USA
(Phocoena phocoena) from the North and Baltic Seas. Z Saugetierkd 61:104-111

> Verfuß UK, Honnef CG, Meding A, Dähne M, Mundry R, Benke H (2007) Geographical and seasonal variation of harbour porpoise (Phocoena phocoena) in the German Baltic Sea revealed by passive acoustic monitoring. J Mar Biol Assoc UK 87:165-176

Verfuß UK, Honnef CG, Meding A, Dähne M, Adler S, Kilian A, Benke H (2008) The history of the German Baltic Sea harbour porpoise acoustic monitoring at the German Oceanographic Museum. In: Wollny-Goerke K, Eskildsen $\mathrm{K}$ (eds) Marine mammals and seabirds in front of offshore wind energy, MINOS: Marine warm-blooded animals in North and Baltic Seas. Vieweg+Teubner Verlag, Wiesbaden, p 41-56

Verfuß UK, Dähne M, Gallus A, Jabbusch M, Benke H (2013) Determining the detection thresholds for harbor porpoise clicks of autonomous data loggers, the Timing Porpoise Detectors. J Acoust Soc Am 134:2462-2468

> Wiemann A, Andersen LW, Berggren P, Siebert U and others (2010) Mitochondrial Control Region and microsatellite analyses on harbour porpoise (Phocoena phocoena) unravel population differentiation in the Baltic Sea and adjacent waters. Conserv Genet 11:195-211

Wood SN (2006) Generalized Additive Models: an introduction with R. CRC Press, London

> Wood SN (2011) Fast stable restricted maximum likelihood and marginal likelihood estimation of semiparametric generalized linear models. J R Stat Soc B 73:3-36

Submitted: July 5, 2012; Accepted: August 27, 2013 Proofs received from author(s): December 10, 2013 